\title{
How to Make and Spend Money: Some Stories from Indian Classical Literature
}

\author{
PHYLLIS GRANOFF \\ Yale University \\ phyllis.granoff@yale.edu
}

Keywords: poverty, wealth, cleverness, avadanas, jatakas, jain prabandhas

DOI: https://dx.doi.org/10.15239/hijbs.02.02.03

Abstract: This paper explores attitudes towards wealth and poverty in early and medieval Indian literature. While poverty is universally decried, stories and plays tell us that wealth brings with it its own problems. First of all, there is the initial problem: how does one acquire wealth? And then there is the question of what a person is to do with wealth once he has it. In answer to the first question, this paper discusses stories that suggest making money required a combination of luck and pluck. A person must recognize a good business opportunity and have the daring-do to seize it. The answer to the second question starts from a verse in the Pañcatantra, which tells us that a man's wealth is not like his wife, to be kept all to himself, but like a public woman to be shared by all. Defining just who is meant by 'all' is the task of numerous religious texts. 


\section{Introduction}

T hardly needs mention that Indian classical texts, religious and secLular, value wealth. Being rich is singled out for praise; it is the just reward for pious deeds. One of the most important aspects of having money is that it allows you to continue to support religious activities, whether by making gifts to religious establishments, feeding ascetics, building temples and donating images, or having sacred texts copied. In many ways, at least theoretically, being rich is self-reinforcing: caused by past merit, it enables a person to continue to make merit and thus to remain wealthy in the future. Some gifts are so momentous that they even result in rebirth in heaven, where the pleasures are that much greater than earthly pleasures. In classical Indian literature, having money is never an end in and of itself; being rich is a good thing because it enables you to do good deeds. By contrast, there is nothing positive about being poor; in a short Buddhist sutta in the Anguttaranikaya, the Inasuttam, 'Sutta on Debt', the Buddha begins his discourse with something that the monks all agree is true: poverty is suffering. ${ }^{1}$

Poverty is often described as the punishment for lack of piety, particularly for lack of generosity to the religious community. Stories that offer examples of the rewards of giving are too numerous to name; one thinks, for example, in Buddhism of the Vimanavatthu and the numerous Avadānas. Similarly, stories that condemn stinginess are found in at least as great abundance, in the Petavatthu, the Avadānas, and elsewhere. Not to be outdone by the Buddhists, the Jains told just as many stories of the importance of being rich and using your wealth to support the faith.

Popular literature, for example the Pañcatantra with its delightful stories and pithy verses, has much to say about the benefits of wealth and the stigma of poverty. Thus, in the chapter on the importance of having friends we read, 'That a man is ever action-ready and lords it over others, that his words command attention, all of this is the

1 AN 6.45: 'Dāliddiyam bhikkhave, dukham lokasmim kāmabhogino' ti? 'Evam bhante', accessed June 24, 2017, https://www.tipitaka.org/romn/cscd/ s0403m2.mul4.xml. 
power of money'. 'Every man is mighty as long as he is rich; every rich man is a sage'. ${ }^{3}$ But, 'Nothing a poor dumb man does ever works out; his doings are as useless as dried up creeks in the heat of summer'. 'As good as dead is a poor man, as good as dead is a childless couple; as good as dead is a funeral feast conducted without a brahmin, and a sacrifice without payment to the priests. ' $P$ 'Peverty is the pinnacle of suffering, for with it comes loss of respect. Even one's own relatives consider a poor man, though he lives, as dead to them' ${ }^{6}$ 'His relatives disown him, and his friends become his foes; this is what befalls the man who no longer has a cent to his name'? But wealth, though treasured, is not meant to be hoarded. Another verse in the Pañcatantra proclaims, 'What use is wealth that is like a wife, kept exclusively to one's self? Wealth is meant to be like a prostitute, enjoyed equally by all and sundry'.

2 Panc 2.88, GRETIL, accessed July 2, 2017, http://gretil.sub.uni-goettingen.de/gretil/1_sanskr/5_poetry/4_narr/vispancu.htm:

yad utsāhì sadā martyah parābhavati yaj janān | yad uddhatam vaded vākyam tat sarvam vittajam balam \|

3 Panc 2.89, GRETIL, accessed July 2, 2017:

arthena balavān sarvo 'py artha-yuktạ sa panditaḅ|

4 Panc 2.91, GRETIL, accessed July 2, 2017:

arthena ca vihinasya purusasyālpa-medhasah | vyucchidyante kriyāḥ sarvā grīsme kusarito yathā

5 Panc 2.100, GRETIL, accessed July 2, 2017:

mṛto daridrah puruṣo mrtam maithunam aprajam |

mrtam aśrotriyam śrāddham mrto yajñas tv adakșinam \|

6 Panc 2.102, GRETIL, accessed July 2, 2017:

daurgatyam dehinām duḥkham apamāna-karam param |

yena svair api manyante jīvanto 'pi mrtāi iva ||

7 Panc 2.104, GRETIL, accessed July 2, 2017:

lajjante bāndhavās tena sambandham gopayantica| mitrāny amitratām yānti yasya na syụ kapardakāḅ ||

8 Panc 2.139, GRETIL, accessed December 27, 2016:

kim tayā kriyate lakṣmyā yā vadhūr iva kevalā | yā na veśyeva sāmānyā pathikair upabbujyate \| 
One of the most sustained reflections on wealth and poverty and this notion that wealth is meant to be given away is to be found in a drama, the Mrcchakatika (The Little Clay Cart). The Little Clay Cart was written by someone called Śūdraka, about whom we know next to nothing. The date of the play in the form in which it has come to us is somewhere around the fifth century CE. ' Cārudatta, the hero of the play, was reduced to penury because he gave all his money away. The play is explicit about this contradiction inherent in normative understandings of the purpose of wealth: if the purpose of being rich is to give money away, it is not hard to imagine a situation just like Cārudatta's, in which giving everything away can make even a very wealthy man poor. As the play opens, Cārudatta laments his poverty in several beautifully crafted verses. He begins by saying that poverty is worse than death; death causes pain but once, while poverty is a constant source of misery. ${ }^{10}$ And what pains him, he continues, is that he has nothing to offer anyone anymore. Would-be guests pass by his house, now that his wealth is exhausted, just as bees no longer buzz around the temples of an elephant once its ichor has dried up. ${ }^{11}$ He knows that there is an element of luck in being wealthy; fate has it that wealth will come and go. Nonetheless, he decries the fact that even his friends deserted him and no longer show him the same affection. ${ }^{12}$ In a verse that echoes chains of causation like the Buddhist Twelve-link chain, Cārudatta sets forth his own theory of the cause of suffering. Poverty, he declares, is the root of all evil; a poor man becomes ashamed of himself and that shame leads him to be disheartened. Disheartened, he is easy prey for those who would oppress him, and oppressed, he becomes depressed. Depressed, he becomes despondent and loses his ability even to think clearly. Not thinking clearly, he is utterly destroyed. The lack of money is surely the root of every possible catastrophe! ${ }^{13}$ Later, when Cārudatta is falsely accused

\footnotetext{
9 Sūdraka, The Little Clay Cart, xx-xvi.

10 Śüdraka, verse 1.11 .

11 Śūdraka, verse 1.12.

12 Śūdraka, verse 1.13 .

13 Śūdraka, verse 1.14 .
} 
of murdering the courtesan Vasantasenā, whom he loves, he knows that defending himself is of no use: no one believes what a poor man says. ${ }^{14}$

For Cārudatta, poverty is a social death. Another character in the play is driven by poverty to steal, suggesting what a Pali Sutta, the Cakkavattisutta states explicitly: poverty is the cause of total chaos in society. In the sutta, there is another causal chain in which poverty plays a major role: Because no one gives charity, poverty increases. And when poverty increases, people begin to steal. When thefts increase beyond a certain point, criminals are punished heavily. This in turn leads to violence and lying and ultimately to a decline in life$\operatorname{span}^{15}$

The Little Clay Cart is not alone in its awareness of the paradox inherent in regarding wealth solely as the means to do good by giving it away, an act that can easily lead to dreaded poverty. Turning to Buddhist story literature, the Jâtakamāla tells the story of a merchant who was the most generous of givers, totally unable to tolerate even the slightest bit of stinginess. The god Indra decides to test him, to see if he can make him keep his wealth for himself instead of giving it away. He arranges things so that the merchant's wealth begins to decrease, but instead of keeping for himself the little that remains, the generous merchant is even more eager to give away what remains. Indra is unmoved. One night he makes even the last vestiges of the merchant's wealth disappear, leaving him only a basket and a pair of shears. The merchant, the Bodhisattva in a previous birth, awakens to find his once prosperous home deserted-not a speck of wealth remains, and even his servants have fled. Like Cārudatta, this generous man, knowing that fortune is fickle, nonetheless laments the loss of his wealth because now those who depended on him must suffer. ${ }^{16}$ He wonders what will happen to all those people who once flocked to his house, accustomed to being honored with gifts, when they find

\footnotetext{
14 Sundraka, The Little Clay Cart, Act Nine: The Trial, pages 396-453.

15 DN 26, 94-95, accessed December 11, 2016, https://www.tipitaka.org/ $\mathrm{romn} / \mathrm{cscd} / \mathrm{s} 0103 \mathrm{~m} . \mathrm{mul} 2 . \mathrm{xml}$.

16 Śūra, Jātaka-mālā, chapter 5, 6.
} 
that he has nothing left to give; he compares their plight to that of thirsty travelers, parched for thirst, who come upon a pond, only to find it dried up. ${ }^{17}$ But the Bodhisattva, unwilling to ask anyone for help, plucks up his courage, and goes out with his basket and cutting tool and cuts grass. He sells the grass and ekes out a meager living, giving what he can to those in need.

Indra is still not convinced that the merchant will continue giving away what little he has, so he shows himself to the merchant in a divine form, making one last attempt to get him to stop being generous:

You were reduced to this pathetic state by your excessive generosity, and by nothing else, not by thieves, nor water, nor fire, nor even by the king confiscating your wealth. I tell you this for your own good: give up your obsession with giving. Poor as you have now become, if you stop giving you will be restored to your former wealthy state. ${ }^{18}$

The merchant declines Indra's offer; what good, after all, is wealth if one does not give it away? Finally, Indra is satisfied that the Bodhisattva is truly generous and that nothing can make him stingy. $\mathrm{He}$ restores his wealth and promises that it will never again be lost and then he disappears. ${ }^{19}$

In the Pāli Jātaka, it is the great merchant Anāthapiṇ̣ika, donor of the Jetavanavihāra, who gives so much that he is reduced to poverty, but nonetheless remains undeterred. As the story opens, we learn that it is not only his generosity that caused his loss of his fortune; many are the merchants who owe him money and whose debts he has not collected. He also lost a considerable amount of money that was buried in pots on a river bank and when the bank collapsed in a storm were carried out to sea. There is a minor goddess living in his mansion and whenever the Buddhist monks or the Buddha comes, being not a Buddhist herself, she is forced to come down from the palace and wait outside. She conspires to make Anāthapiṇịika stop

17 Súra, Jātaka-mālā, chapter 5, 7.

18 Śūra, chapter 5, 8-9.

19 Śūra, chapter 5, 24-30. 
supporting the monks and urges various people in his employ to speak to him, but to no avail. When she sees that he has finally been reduced to penury by all his support to the Buddhists, she gets the courage to speak to him herself. This too fails, and she leaves his mansion to search for another place to settle. When she finds none, she takes the advice of the deity who protects the city. He advises her to recover Anāthapiṇ̣ika's wealth, by making the merchants who owe him pay up and by using her power to recover the lost jugs that were at the bottom of the ocean. All this she does and begs forgiveness of Anāthapiṇ̣ika. A story with a happy ending, to be sure, but one that is also aware of the finite nature of wealth and the ultimate end of untrammeled generosity. ${ }^{20}$

The Jains had an answer to the problem posed by the unbounded generosity of Cārudatta and the Bodhisattva as merchant. Lay Jains were to set limits on their wealth; anything that they made over that set amount was to be spent in charity, on seven areas that were earmarked for pious donations: images of the Jains, temple building, copying of Jain texts, donations to monks, donations to nuns, and assistance for Jain laymen and laywomen. If medieval stories are any guide, setting the limit to one's wealth was a formal ritual, done in the presence of a Jain monk. In one story, to which I return below, a monk names an amount for a poor merchant that seems beyond his wildest dreams. Setting the limit to one's property here acts as a prophecy of wealth to come.

The notion that wealth is desirable and that it should be given away is a powerful and shared idea that is not exclusive to any one religion. While greed and stinginess are condemned, making money is seen as something positive. The Jain monk Hemacandra acknowledged that making money has a negative side in that it involves harming living beings and thus violates the most important Jain rule against doing violence to living beings. For this reason, a person should not seek to make money simply in order to make religious donations. Nonetheless, a person who is a householder, and there-

\footnotetext{
$20 \mathrm{Ja}$ 40, accessed July 4, 2017, https://www.tipitaka.org/romn/cscd/s0513m. mul0.xml.
} 
fore still embedded in the world of possessions and violent actions, must earn to support his family. So that his skill in making money may yet yield a great positive fruit that counterbalances the negative deeds that are inevitable for a householder, he should spend all he can on religious deeds, building temples, installing images and copying texts. ${ }^{21}$

A passage in the tenth chapter of the tenth book of the Bhägavata Purāna, which praises poverty as the magic healing unguent that cures the blindness of addiction to wealth and sees having wealth as a slippery slope leading to carousing with women and drinking, is clearly a minority view. ${ }^{22}$ The majority opinion is that for those who do not renounce, poverty is terrible and making money is a very good thing indeed, as long as one gives generously. In what follows, I examine some stories that give us clues as to how a person goes about making money. We shall see that it requires courage, persistence, a measure of luck and the wit to know how to seize an opportunity when it presents itself. Occasionally it requires past merit, but the stories I review here are more interested in what a man can do in the here and now to become rich than they are in what he did in a past life that contributes to his success in the present life. We shall see that the means by which a man becomes wealthy may even involve practices we might consider to be ethically suspect and were indeed condemned in prescriptive texts, but our stories nonetheless praise them as examples of clever business practice.

\section{Courage and Daring-do}

In the Jätakamālà story of the Bodhisattva as the generous merchant reviewed above, the merchant is described with an adjective often used for the Bodhisattva and the Buddha: mahāsattva, 'having

\footnotetext{
21 Yogaśāstra, commentary on 3.120, page 587.

22 Bhāgavata purāna 10.10.13-10.10-17, GRETIL, accessed January 2, 2017, http://gretil.sub.uni-goettingen.de/gretil/1_sanskr/3_purana/bhagp/bhp_10u.htm.
} 
great courage'. We shall see in a moment that the term might also be rendered, 'having great pluck' or 'having a spirit of daring-do'. In any case, it is something along those lines. Here, I would argue, the adjective has special significance and tells us of a character trait that is essential to those who would accumulate a fortune. If you are going to make money, you must have gumption, determination, fortitude, and courage, or something that combines them all-sattva. The story tells us that the Bodhisattva has all these things. When the Bodhisattva wakes up to find nothing left to him but a rope container and a cutting tool, he relies on his natural resolve (svadhairyāvastambhād) and does not succumb to faint-heartedness or despair but sets off to do what he needs to do to survive (anāsvāditavișädadainyas).

The Jain Prabandhas, diverse collections of biographical legends about famous monks, kings and lay people, preserve a story of King Vikrama that tells us that sattva, 'courage', 'daring-do', 'pluck', is in fact the key to success in acquiring and keeping one's fortune. I translate the version from the Purātana Prabandhasamgraba. A slightly different version of the story appears as well in the Prabandhacintamani of the Jain monk Merutunga, composed in $1304 \mathrm{CE}$ and translated by Tawney in Wishing Stone of Narratives:

At one time, word circulated far and near that in the city of Ujjaiyini anything and everything could be sold. One king decided to put this to the test, thinking to himself, 'I will send something that no one will take'. He had an anthropomorphic image of poverty made from iron. This Poverty-man held the sun in one hand and a broom in the other. Having had the image made, he handed it over to a trader. 'Take this to Ujjaiyinī. After you have sold all your wares, show this image. Demand for it the price of one lakh. If no one buys it, then raise a hue and cry at the city gate, putting the lie to the vaunted fame of that city. Then you may return'. He went there and sold everything. Some merchants asked him, 'What do you have left in your cart? Let us see'. He showed them the Poverty-man. They asked, 'What on earth is that?' When he said its name, they all shut their eyes tight and ran away. He shouted after them, 'Buy this for one lakh! Don't let the reputation of your city be stained!' But everyone 
fled far away. He took the thing to the city gate and proclaimed, 'No one bought our Poverty-man. We will be off now, but the stain on your city remains'. The king summoned him, and he brought with him the Poverty-doll. The courtiers all shut their eyes tight at the sight of it. The king bought it for one lakh. He put it in his treasury. That night, in the first watch of the night as he lay fast asleep, a man came to the king and said, 'King, I'm leaving'. The king asked, 'Who are you?' 'The superintending deity of the elephants'. 'Why are you leaving?' 'Because you bought Poverty. Where there is poverty, how can there be elephants?' 'In that case, then be off'. After he left, in the second watch of the night, a woman came and said, 'King! I am leaving'. 'Who are you?' 'I am the Goddess of Wealth'. 'Why are you leaving?' 'Now that you have bought Poverty, how can there be wealth? My followers are going with me'. 'Get out of here'. And then in the third watch of the night, a man came and said, 'King, I am going'. 'Who are you?' 'I am Daring-do personified'. The king said, 'Don't go'. 'Why did you buy Poverty? Where there is poverty, how can there be Daring-do?' The king said, 'I could buy it because I have Daring-do. Those who do not have it, don't you see, none of those dared to buy it. If you go, then it will be over my dead body'. And with those words the king drew his sword. He said, 'King, don't! Where I am, there wealth is, with all its trappings'. The next morning the king had the Poverty-man brought to the court. He told the courtiers what had happened during the night and then got rid of the Poverty-doll. ${ }^{23}$

The king uses the word sāhasa, a synonym of sattva, the attribute of the merchant in the Jätakamālà. It means courage, daring, a willingness to venture in search of a goal even where there is threat to one's life. The king in this story is able to keep his wealth by having the courage to sacrifice his own life if need be. In the version in the Prabandhacintāmani, King Vikrama has these words for Sattva: 'Oh Sattva, wealth, virtue, and blazing glory, all these exist only as long as you sport in the city that is my mind. I would let my king-

\footnotetext{
23 Purātanaprabandasamgraha, 2; Tawney, Prabandhacintāmaṇi, 10.
} 
dom go, my women, and even my fame, but never would I let you leave me'. ${ }^{24}$

This little vignette about King Vikrama makes explicit what is implicit in all the stories of merchants who journey afar to amass wealth. Buddhists, Jains and Hindus alike told fabulous tales of merchants who crossed the sea or the mountains in search of wealth and risked their lives doing so. We think of the merchant Pūrna in the Divyāvadāna, to whom I will return in a moment; of Simhala in the Buddhist Gunakarandavyūha and his Jain counterpart in the Jñatādharmakathā; of Cārudatta in the Jain Vasudevabindi and the Hindu Brhatkath $\bar{a} \cdot{ }^{25}$ And there are so many others. Warned of the dangers, these plucky merchants summon up all their courage and bravely set forth. In all these stories, becoming rich demands bravery, daring-do, and courage, but that is just the start. To make money in these stories, the hero also needs to know a good deal when he sees one.

\section{Making a good deal or seizing an opportunity when it presents itself}

Perhaps one of the best-known stories about making a good deal is the story of Pūrna told in the Divyāvadāna. Pūrṇa is on his way to the market when he just happens to see a man carrying a load of wood. The man is shivering, but is unable to explain to Pürna why, only that as soon as he picked up the wood he began to shiver. Pūrna knows wood and he realizes that the man is carrying ox-head sandalwood, a rare wood of great value. He asks the man how much he wants for the load, and the man names a price of five-hundred coins. Pūrna takes the wood to the market. He sells four small pieces for a thousand coins and pays off the woodsman. Eventually he will sell more of it to the king as a medicine for fever for another one thousand coins, and when the king summons him and wants still more he

\footnotetext{
24 Tawney, Prabandhacintāmaṇi, 5.

25 Granoff, 'Speaking of the Sea'.
} 
offers him four measures of the sandalwood but takes payment for only three. This earns him the king's favor, but he made a fair profit, even so. The king paid him a lakh of gold for each measure! ${ }^{26}$

Now it might seem as if Pürna was not quite honest with the woodsman, but being smart enough to recognize a good thing when you chance upon it seems to have been something valued. The Jains told similar stories, in their case of merchants who struck it rich by recognizing that a goat was wearing a precious jewel around its neck, something that somehow escaped the notice of the original owner of the goat. I translated one version of the story that appeared in Rājaśekhara's Prabandhakośa, written in 1349 CE. Here is the episode from a shorter version in the Purātanaprabandhasamgraba: ${ }^{27}$

Because of his former bad karma, Ābhaḍa began to lose all his money. His wife took their children and went back to her father's house. Ābhada, now all alone, worked in the jewel market, polishing little bells. He received only a measure of grain and that was all he had to live on. He ground it himself, cooked it himself, and ate it by himself. Thus, he passed days in terrible poverty. As it is said, 'If the Goddess of Wealth did not stay forever with the ocean or the God Viṣnu, both of whom held her close with great affection, then how could anyone expect that She would remain forever with an ordinary merchant?'

One day Ābhada went to the hall in which his family preceptor, the Jain monk Hemacandra, observed the Pausadha fast. When he saw that the monk was setting the limits for wealth for lay Jains, he too asked for a limit to his wealth. He asked the monk how many drammas he would have. Knowing his worth, the monk wrote down nine lakhs of drammas. And he listed other things. He showed the list to Ābhadia, who said, 'This must be for someone else, who has great merit. I am not worthy of this'. The monk replied, 'You will

26 Divyāvadāna, GRETIL, chapter 19, accessed December 14, 2016. The story is translated by Tatelman, The Glorious Deeds of Pürna.

27 Purātanaprabandhasamgraha, 33. My earlier translation is in Granoff, 'Biographical Writings', 131-59. 
have this much. Whatever you make beyond this amount you must spend for the Faith'. In time, Ābhada made five drammas. One day he bought a she-goat at the town crossroads for five dīnāras. The goat had a jewel around her neck and that came with her. He had a jeweler cut the jewel into pieces and in time became wealthy. His family returned to him.

One of the manuscripts elaborates upon the goat and the jewel. Ábhada notices the jewel around the goat's neck and realizes it is an emerald. He asks the seller how much he wants for the goat and the price is just five dinnaras. The goat seller tries to take the jewel off the goat's neck but Ābhada will not let him. He shows the stone to a jeweler who cuts it and makes stones each worth a lakh. In this way, he became a very rich man. With this addition, the text makes explicit what we might have suspected from Pūrna and the sandalwood: Ábhada knows that the stone around the goat's neck is something extraordinarily valuable and is happy to get it for a song.

A similar story is told of another Jain merchant, Jagadū, who is celebrated for his famine relief at the time of a great famine in Gujarat in 1256-1258. One day the fortunate Jagadū happened to find himself on the outskirts of the city. He saw a goat herder with his herd of goats. One of the she-goats had an amulet, a stone, around its neck and seeing that, Jagadū thought to himself, 'A jewel like that can only be noticed by someone whose luck is good. That jewel is the means to gain great wealth. If I can get it for myself all my desires will be fulfilled'. Thinking that, he gave to the goat herder a paltry sum and took the goat home. That clever man removed the wealth-granting amulet from the goat's neck and secretly worshipped it in his house. Through the power of that amulet, Jagadū's wealth increased, just as meditation grows strong for the person who has a pure mind. ${ }^{28}$

In the case of Jagadū's goat, it might be best to translate mani not simply as 'gemstone', but as amulet, one of the common meanings of mani. This is suggested by the fact that Jagadū worships the object,

\footnotetext{
28 Jagadūcarita, chapter 3, verses 11-16.
} 
rather than taking it to a jeweler and having it cut. Nonetheless, like $\bar{A}$ bhada Jagadū recognizes the value of the object and pays the owner a small price, kiñcana dhanam as the text says. He also worships it in secret, pracchannam, and the text tells us that this was all very clever of him. It calls him vicaksana, 'smart'. ${ }^{29}$

In all these stories, chance or good karma does play a role, but the merchant is praised for seizing the opportunity however it presents itself. None of our protagonists could be called risk-takers; Jagadū, Ábhaḍa, and Pūrṇa are all smart and know what they are getting. But, sometimes a combination of chance and sheer stubbornness can insure wealth, even when a person is not particularly clever. In another episode in the account of Jagadū, his agent triumphs over a rival buyer by sheer persistence and stubbornness. Having gone by sea to Ârdrapura, Jagaḍu's agent, Jayantasimha, finishes his trades and is about to set off when he gets in an altercation with a local over something he tries to take with him. The object they are fighting over is an odd one; it seems to be just an ordinary rock. Jagadū's man ends up paying a fortune for it, just to save his master's honor, but the rock turns out to be no ordinary rock, unbeknownst to any of the actors. With the rock loaded on his ship, Jayantasimha sets off, to the praise of all the bystanders who praise his pluck, his sāhasa. Jagadu sets the rock in his courtyard, where it stays pretty much unnoticed until a deity comes and tells him to break the stone open. Jewels tumble out of the rock. Buying this stone, too, turns out to have been a good deal, and we are back where we started: with someone's daring-do, pluck, or courage, becoming the source of untold wealth. ${ }^{30}$

The stories of the rare sandalwood and the gem around the neck of the goat celebrate the cleverness of purchasing something of great value for very little money. After all, Pūrṇa, Abhaḍa, and Jagaḍu knowingly offer the hapless owners of the wood and goat a pittance for their rare treasures. What is so striking about these stories is that they celebrate ways of doing business that prescriptive texts condemn. In the Jain Yogaśāstra of Hemacandra, the first require-

\footnotetext{
29 Jagadūcarita, chapter 3, verse 15 .

30 Jagadūcarita, chapter 4 .
} 
ment for a lay person is that his wealth must be lawfully acquired, nyāyasampannavibhavah. Hemacandra explains that a person must not acquire wealth by cheating his friends, deceiving someone who trusts him or by stealing. ${ }^{31}$ In explaining the nuances of stealing, another text on lay behavior, the Kärttikeyānuprekșā, considers as theft the acquisition of a valuable object for a low price, exactly what our protagonists are praised for doing. ${ }^{32}$ Other texts list alternative business practices that a merchant must avoid; these include tampering with the scale in his own favor, so that when he is the seller the buyer gets less than he should or when he is purchasing something the seller gets less than his due. A person must also not adulterate expensive goods with cheap substitutes. Such acts are considered violations of the precept that prohibits stealing. ${ }^{33}$ It is not difficult to see that behind these examples is a simple principle: a merchant should not profit by giving less than a fair value for what he buys or sells.

Engaging in dishonest business practices was also widely condemned in Buddhist sources. The Brabmajälasutta prohibits a monk from buying and selling, and further prohibits him from cheating with scales or measures. ${ }^{34}$ In his commentary on this passage, Buddaghosa goes to some length to explain what cheating with scales involves. There are four types of cheating with scales. In the

\footnotetext{
31 Hemacandra, Yogaśāstra, 1.47, 144-145.
}

32 Kärttikeyānuprekșā, 335, 242. The commentary by Śubhacandra interestingly explains this as obtaining valuable objects such as gems, jewels, pearls gold, camphor, musk, silk, silver and coins by means of cheap things like counterfeit money, fake gems, coarse cloth and so on. I take this to mean that when someone offers a valuable jewel, etc., for sale, the buyer says that it is fake and pays him little, although he knows it is of great value. This is close to what our protagonists in fact do. Subhacandra completed his commentary in $1556 \mathrm{CE}$. The text itself is difficult to date but was completed sometime between tenth to thirteenth century CE.

33 Làțìsambitāe, 5.54-56, pages 116-117; Uvāsagadasāo, 1.47.

34 DN 1, paragraph 10, accessed June 27, 2017, https://www.tipitaka.org/ romn/cscd/s0101m.mul0.xml: Kayavikkayā pațivirato samaṇo gotamo.... Tulākūtakamsakūtamānakūțā pațivirato samaṇo gotamo.... 
first one, called rüpakutta, cheating by the appearance of the scale, a person has two scales of exactly the same appearance, but they weigh things differently. When he is buying, he uses the scale that weighs light so that he gets more. When he is selling, he uses the scale that weighs heavy so that a small quantity appears to be heavier than it is. Second, 'cheating with the body', or angakūta, involves putting a finger on the scale to alter the weight when buying and selling. Third, gabanakutta involves holding the scale differently when selling or buying. The fourth, paticchannakutta 'cheating by concealing', involves filling the scale with iron filings in such a way that the weight is altered. ${ }^{35}$ The other dishonest practices prohibited include passing off brass as gold, cheating on the amount of oil sold or grain sold by manipulating the opening of the container.

In the Nimi Jâtaka, King Nimi, on his trip to hell, sees beings tormented by dreadful thirst. When they attempt to drink from a river, the water turns into chaff. He asks his guide, Indra's charioteer Mātali, what terrible deed these beings committed that they should now have to suffer such a punishment. Mātali explains that they cheated in business. They adulterated the grain they sold by adding chaff. The prose section further elaborates; these wicked merchants had taken money from their customers, proclaiming that they were selling them pure grain, and mixed in chaff, even sand or dirt. ${ }^{36} \mathrm{Next}$, Nimi sees people being pierced with arrows, lances and spears. He is told that these are people who took from others what was not given

35 DN 1, paragraph 10, accessed June 27, 2017, https://www.tipitaka.org/ romn/cscd/s0101m.mul0.xml: Kayavikkayāti kayā ca vikkayā ca. Tulākūțādìsu kūtanti vañcanam. Tattha tulākūțam nāma rüpakūțạ an்gakūtam, gabanakūtam, pațichannakūtanti catubbidham hoti. Tattha rūpakūtạn nāma dve tulà samarūpā katvā gaṇhanto mahatiyà gaṇhāti, dadanto kbuddikāya deti. Angakūțạ nāma gaṇhanto pacchābhāge hatthena tulam akkamati, dadanto pubbabhāge. Gahanakūtạn nāma gaṇhanto mūle rajjum gaṇhāti, dadanto agge. Pațicchannakūtạn nāma tulam susiram katvā anto ayacunnam pakkhipitvā gaṇhanto tam pacchābhāge karoti, dadanto aggabhāge.

36 Ja 541, verses 471-474, accessed June 4, 2017, https://www.tipitaka.org/ $\mathrm{romn} / \mathrm{cscd} / \mathrm{s} 0514 \mathrm{~m} . \mathrm{mul} 5 . \mathrm{xml}$. 
to them; in other words, who stole from others. The prose explains that such theft takes place not only by breaking and entering, but also by cheating or deceiving someone. ${ }^{37}$ Not to take what is not freely given is one of the cardinal Buddhist precepts and its violation is the definition of theft. For monastics, it is grounds for expulsion from the community; a monk who steals can be seized by the king, executed, imprisoned or exiled, while the king could loudly proclaim him to be a thief and a fool. ${ }^{38}$ For lay men and women, the Nimi Jàtaka tells us, the punishment is torment in hell. Nimi also sees the torments in hell of merchants who used false weights and did not give people an honest price for their goods. ${ }^{39}$

If they are not reborn in hell, dishonest merchants are nonetheless destined for a terrible rebirth. The commentary to the Udana tells the story of Sona, who in the Anguttaranikāya Etadaggavagga is named the foremost of those who speak beautifully. Before he renounced, Sona was a merchant. One day he traveled to Ujjeni with a caravan. As they settled in for the night, he chose a spot away from the others, hoping for a quiet sleep. He slept too well and in the morning the rest of the caravan forgot about him and left him behind. He made his way alone, and when he reached a banyan tree he saw a gigantic hideous man who was eating his own flesh. $\mathrm{He}$ asked him who he was and learned that he was a peta, who in his previous life was a merchant in the thriving port city of Bhārukaccha. He was condemned to his horrible rebirth as a hungry ghost because he cheated others out of what belonged to them. ${ }^{40}$

37 Ja 541, verses 475-477 and prose.

38 Prātimokṣa sūtra_Pār.2, GRETIL, accessed January 3, 2017, http://gretil. sub.uni-goettingen.de/gretil/1_sanskr/4_rellit/buddh/prmosu_u.htm: yah punar bhikșur adattam steyasamkhyātam ādadyād yathārūpeṇādattādānena rājō by enam gṛhìtvā hanyād vā badhnīyād vā pravāsayed vā evam cainam vadec coro 'si


vaty asamuāsyah 2.

39 Ja 541, verses 490-491 and prose.

40 Ud 5.6, accessed July 24, 2017, https://www.tipitaka.org/romn/cscd/ s0503m.mul4.xml. 
Dishonest business practices were universally condemned. The Laws of Manu has a long section on the punishment of thieves, and we have seen that dishonest business practice is considered to be a form of theft. More specifically, a person who adulterates grain, like the culprit in the Nimi Jâtaka, may also be reborn deformed. Someone who steals gems or precious substances is reborn as a bird. ${ }^{41}$ The Assamese Dharmapurāna, known from an illustrated manuscript now in the British Library dated 1735/1736, depicts merchants who were dishonest in buying and selling being tortured in hell. ${ }^{42}$

These stories that I reviewed here are all about unusual situations that prompt a clever merchant to underpay a seller. There are also stories of over-charging. Another Buddhist Jàtaka praises the cleverness of a merchant who makes his fortune by taking advantage not only of an opportunity, but also of his fellow men by artificially creating a scarcity of something that they need. In the Cülasetthijataka, we meet a very clever merchant, Cūlasețthi, who is the Buddha in his past life. ${ }^{43}$ Cūlasețthi sees a dead mouse on the road, and calculating the position of the stars, he pronounces that a clever young man could make a fortune with it. A poor fellow overhears him and picks up the mouse. He sells it to someone who has a cat and with the few coins he gets some molasses. He gives some of the molasses and a ladle-full of water to some flower sellers who are returning from the forest and they in return give him a few handfuls of flowers. He turns the flowers into more molasses and with his trade in molasses and water earns some more. Luck helps him; a wind storm blows down branches and dried leaves in a garden and when the gardeners can not clear all the rubbish, he agrees to do it for them if they pay

41 The Law Code of Manu, 11.51 and 12.62. On 12.62, the rebirth for a jewel-thief, I follow the alternate explanation of the commentators, that the thief is born as a bird. Translated by Olivelle, 193, 215.

42 The manuscript was first briefly described by. L. D. Barnett, 'Two Illustrated Assamese Manuscripts', 1-12. It is Or.11386.

43 Ja 4, accessed January 2, 2017, https://www.tipitaka.org/romn/cscd/ s0513m.mul0.xml. The story is also told in Ud 5.10, accessed July 24, 2017, https://www.tipitaka.org/romn/cscd/s0503m.mul4.xml. 
him by letting him keep the refuse. He sells the branches and leaves to the royal potters who need fuel to fire pots for the king. So far, everything seems to be above board, but then the deals get more complicated. The young man next gives water to some grass cutters and tells them to keep his payment in reserve. In the meantime, he has made friends with a merchant who trades overland and another merchant who trades by sea. He learns from the overland merchant that a shipment of 500 horses is about to arrive. He tells the grass cutters that as payment for his previous service they are to give him a huge amount of grass and to refuse to sell anyone any grass until all his grass has been sold. The traders come with the horses and when they cannot get any grass to feed them they are forced to pay the young man a thousand coins for his grass, clearly way beyond the normal price. Then it is time for him to use the inside information his sea merchant friend provides. The ocean-going merchant tells him that a large ship has come into port. The young man hastens to the port and purchases the contents of the ship on credit. A hundred merchants from Benaras arrive on the scene, eager to buy the goods. Each of the hundred merchants gives him a thousand coins to reserve a share of the goods and then another thousand to purchase the goods outright. Our man is now rich. He reports his success to Culasețthi and is given his daughter in marriage. There is nothing but praise for the young man's deeds.

The basic plot of the story of making money starting with a dead mouse is familiar to every first-year Sanskrit student. The version of the story about a man who gets rich starting only with a dead mouse appears in the Kathassaritsägara and is one of the selections in Lanman's Sanskrit Reader. Comparing the two versions is telling. The young man in the Kathäsaritsägara is basically clever and honest; he starts with the mouse, buys chickpeas and takes water, which he gives to some woodcutters who are returning exhausted from the forest. In return, he gets wood from woodcutters. He sells the wood they give him and eventually is able to buy up all the wood that they cut in the forest. He makes a killing when the price of wood suddenly goes up because of a heavy rain that causes a scarcity of fire wood. The young man in the Kathāsaritsāgara has not caused the scarcity, only taken advantage of it. Our young man in the Buddhist 
story, by contrast, creates the very scarcity that makes him rich. He has the grass cutters refuse to sell their grass to the horse merchants and so is able to charge them a fortune. He also gets inside information about the docking of the ship, which allows him to lay claim to all its merchandise and then resell it at an extraordinarily high price to the merchants from Benaras. Clever deals, to be sure, but I would suggest that there are indications these could be seen as problematic. Jagaḍu worships his jewel in secret, as if there is something not quite right about his having it, and the Kathāsaritsāgara takes pains to make it clear the merchant with the mouse does not cause the scarcity of wood but merely recognizes the opportunity in the untimely rain that reduced the supply of fire wood.

Not all stories of starting from something worthless and earning a fortune necessarily imply a measure of deceit, as the next story illustrates. The Jain tale Kuvalayamālā exists in two versions. The original text was written in Prakrit by Uddyotanasūri in 779 CE. A shortened Sanskrit version was completed by another Jain monk, Ratnaprabhasūri, in the thirteenth century CE. In one episode, a young trader, appropriately named Lobhadeva, 'The One Whose God is Greed', following the local custom, joins an informal meeting of merchants before setting off to return home. In the Prakrit version, the merchants simply gather to exchange random information about where they have been and what they have bought and sold. In the later Sanskrit version, the topic of their conversation is more specific. One trader wants to know where, if anywhere, someone has been able to gain something of great value by means of something of little worth. One of the merchants present boasts that he was able to parlay leaves of the Neem tree into gemstones on distant Jewel Island. ${ }^{44}$ Hearing this, Lobhadeva decides not to return home but to sail for Jewel Island. While the voyage to Jewel Island is fraught with peril, there is no hint that the commerce he engaged in there was unusual. In fact, in its ordinariness, Lobhadeva's trading makes the stories of acquiring the precious sandalwood and the goat's jewel stand out as tales of the extraordinary. Lobhadeva is by no means

44 Kuvalayamālā Part II Sanskrit text, 22 and part 1, Prakrit text, 65. 
purely honest, however; on his return, his greed gets the better of him and he murders his companion so that he can keep all the jewels they acquired for himself. No good comes of this, and we are alerted to the fact that daring-do may bring one wealth, but other factors are necessary if a person is to keep the wealth he acquired.

This is also the point of a story in the Pañcatantra, which accepts the general view that determination and cleverness are necessary if one is to acquire wealth, but aims to show that they are not sufficient for keeping it. This is the story of Somilaka the weaver, who produces cloth so fine and so beautifully patterned that it is fit for a king. Despite this, he earns just enough to feed himself and his wife, while the other weavers, who make only coarse cloth, have all become rich. Somilaka tells his wife that he is fed up with their village, where he can barely make a living, and is going to go elsewhere to try his luck there. They argue and Somilaka convinces her that only those who exert themselves and take some initiative succeed, and off he goes. After three years of working in a distant city, he earns three hundred gold pieces and sets off for home. As night falls, he climbs up into the roots of a banyan tree so that wild animals will not find him and falls asleep. He hears voices. One is the voice of karma and the other is the voice of Individual Resolve. Karma warns Individual Resolve, 'Don't you know that this Somilaka will never have any more money than the bare minimum, just what is necessary for him to feed and clothe himself? Why did you give him three hundred gold pieces'? Individual Resolve responds, 'I always give to those who are determined to succeed. It's up to you what happens after that'. Somilaka awakens to find his money gone. He goes back to the city and works so hard and so cleverly that in a year he makes five hundred gold pieces. This time on his way back he does not even stop to rest, but he sees the same two figures approaching him. Once again, he hears the same conversation and suffers the same loss of everything he earned. In this story, resolve and determination lead one to succeed in making money, but not in keeping it. That requires the right karma. ${ }^{45} \mathrm{~A}$ verse in the

45 Pañcatantra, Kathā 5, GRETIL, accessed December 29, 2016, http:// gretil.sub.uni-goettingen.de/gretil/1_sanskr/5_poetry/4_narr/vispancu.htm. 
Mahābhärata admonishes that it is not only making money that requires cleverness; staying rich also requires some smarts, 'Wealth once acquired vanishes if you are not smart enough to keep it', ${ }^{46}$ the verse warns.

Such cautionary comments and the Pañcatantra vignette about Somilaka's misfortunes nonetheless still leave out of the equation something that scholars who studied traditional business culture in India considered one of its fundamental characteristics, namely that crucial to success in business is a reputation for honesty and fairness, for modesty and even piety, and not any renown for the ability to make sharp deals or secure handsome gains. ${ }^{47}$

\section{Conclusions}

The stories reviewed in this paper tell us that it is a combination of extraordinary courage and smarts, combined with good luck or good karma, that makes people rich. Told in every one of India's classical religions, Buddhism, Jainism and Hinduism, the stories share a sense of admiration and even wonder at the acquisition of wealth accomplished through determination, fearlessness, and a wily ability to recognize and exploit opportunities that present themselves. The rich are admired precisely because they are rich.

However, these stories, like all good stories, are not quite as simple as they seem and they raise a number of questions. None of the stories exists in a vacuum; they all are part of a complex literary, religious and social world. To some extent, their effectiveness depends on the many ways in which they toy with the norms of that larger world. In this essay, I singled out their departure from the norms of proper business practice that we find in prescriptive literature and that we know from studies of traditional business culture. The morality of these stories seems closer to what we find in texts like the Pañcatan-

\footnotetext{
46 Mahābhārata 3.190.34c

47 Dalmia, Fiction as History, 69, particularly note 31 citing Dundas, The Jains, 169.
} 
tra, where cleverness and the skillful manipulation of circumstances, even trickery, lead to success. ${ }^{48}$ Nonetheless, a place for moral behavior and piety is found in the stories of vanishing wealth and the assertions that the purpose of making money is to give it away, to spend it in religious donations. It is not enough to make money, one must be able to keep it and know how to use it. The stories, then, are but one small section of a larger picture, to which they add nuance and color.

\section{Bibliography}

\section{Abbreviations}

AN Anguttaranikaya.

DN Dighanikaya.

Ja Jatakapali.

Panc Pañcatantra. See Bibliography, Primary Sources, Viṣnuśarma.

Ud Udanapali.

\section{Primary Sources}

AN 6.45 Inasuttam. Pali Tipitaka. Accessed June 24, 2017. https:// www.tipitaka.org/romn/cscd/s0403m2.mul4.xml.

Collection of Old Prabandhas (Purātanaprabandhasañgraha):

Purātanaprabandhasangraha. Edited by Jinavijaya Muni. Singhi

Jain Series 2. Calcutta: Singhī Jaina Jñānapịtha, 1936.

DN 26 Cakkavatisuttam. Pali Tipitaka. Accessed December 11, 2016. https://www.tipitaka.org/romn/cscd/s0103m.mul2.xml.

Divyāvadāna. GRETIL - Göttingen Register of Electronic Texts in Indian Languages. Accessed December 24, 2016. http://gretil. sub. uni-goettingen.de/gretil/1_sanskr/4_rellit/buddh/divyav_u.htm/. Ja 4 Cülasețthijätakam. Pali Tipitaka. Accessed January 2, 2017. https://www.tipitaka.org/romn/cscd/s0513m.mul0.xml.

\footnotetext{
48 On the morality of niti literature see Dalmia, Fiction as History, 87.
} 
Ja 40 Khadirangarajataka. Pali Tipitaka. Accessed July 4, 2017. https://www.tipitaka.org/romn/cscd/s0513m.mul0.xml. Jātaka-mālā. By Ārya Śūra. Edited by P. L. Vaidya. Darbhanga:

The Mithila Institute of Post-Graduate Studies and Research in

Sanskrit Learning, 1959.

Kārttikeyānuprekșā. Agās: Śrīmad Rājacandra Āśrama, 2005. Kuvalayamālā's Story (Kuvalayamālākathā) of Ratnaprabhasūri:

Uddyotana-süri's Kuvalayamālā, Part II: Ratnaprbha-süri's [sic]

Kuvalayamālā Kathā. Edited by A. N. Upadhye. Singhi Jain

Series 46. Bombay: Bharatiya Vidya Bhavan, 1970.

Làtīisambitā. Vol. 3 of Śrāvakacāra-samgraha, edited by Hīralāla

Śastrī. Solāpūra: Jaina Saṃskṛti Saṃrakṣaka Saṃgha, 1977.

The Law Code of Manu. Translated by Patrick Olivelle. Oxford:

Oxford University Press, 2009.

Manorathapürañi, Etadaggavagga, Cülapanthakatheravatthu.

Accessed July 24, 2017. http://www.tipitaka.org/romn/.

Ja 541 Nimijātaka. Pali Tipitaka. Accessed June 4, 2017. https:// www.tipitaka.org/romn/cscd/s0514m.mul5.xml.

The Prabandhacintamani or Wishing-Stone of Narratives. Translated by C. H. Tawney. Calcutta: Asiatic Society of Bengal, 1901.

Prātimokșa sutra. GRETIL - Göttingen Register of Electronic Texts in Indian Languages. Accessed January 3, 2017. http://gretil.sub. uni-goettingen.de/gretil/1_sanskr/4_rellit/buddh/prmosu_u. htm.

Sarvānandasūri. Jagadūcarita. Edited by Sādhvī Candanabālāśrī. Ahmedabad: Bhadrankara Prakāśan, 2008.

Texts in Indian Languages. Accessed January 3, 2017. http:// gretil.sub.uni-goettingen.de/gretil/1_sanskr/4_rellit/buddh/ prmosu_u.htm.

Ud 5.6 Sonasuttam. Pali Tipitaka. Accessed July 24, 2017. https:// www.tipitaka.org/romn/cscd/s0503m.mul4.xml.

Uvāsagadasāo. Edited and translated by August Friedrich Rudolf Hoernle. Calcutta: Asiatic Society, 1890.

Viṣnuśarma. Pañcatantra. GRETIL - Göttingen Register of Electronic Texts in Indian Languages. Accessed December 29, 2016. http:// gretil.sub.uni-goettingen.de/gretil/1_sanskr/5_poetry/4_narr/ vispancu.htm. 
Súdraka. The Little Clay Cart. Translated by Diwakar Acharya. The Clay Sanskrit Library 44. New York: New York University Press, 2009.

Wishing-Stone of Prabandhas (Prabandhacintāmani) of Merutunga: Prabandhacintāmani. Edited by Jinavijaya Muni. Singhi Jain

Series 1. Shantiniketan: Singhī Jaina Jñānapītha, 1931.

Yogaśāstra. By Hemacandra. Edited by Vijaya Dharma Sūri.

Bibliotheca Indica 172. Calcutta: Asiatic Society, 1907.

\section{Secondary Sources}

Barnett, L. D. 'Two Illustrated Assamese Manuscripts'. The British Museum Quarterly 8, no. 1 (1933): 1-12.

Dalmia, Vasudha. Fiction as History: The Novel and the City in Modern North India. Delhi: Permanent Black, 2017.

Dundas, Paul. The Jains. London and New York: Routledge, 1992.

Tatelman, Joel. The Glorious Deeds of Pürna: A Translation and Study of the Pürnàvadana. Surrey: Curzon, 2009.

Granoff, Phyllis. 'Biographical Writings Amongst the Śvetāmbara Jains in Northwestern India'. In According to Tradition: Hagiographical Writing in India, edited by Winand M. Calleweart and Rupert Snell, 131-59. Wiesbaden: Otto Harrassowitz Verlag, 1994.

- _ - 'Speaking of the Sea: The Mystery of Jain Travel Narratives'. In a volume edited by Osmund Bopearachchi, forthcoming. 